\title{
On the Improvement of the Citizens' Legal Security
}

\author{
Quan-Yi LI ${ }^{1, a}$, Yuan XIN²,b \\ ${ }^{1}$ Law and Political Science Department, North China Electric Power University, China \\ ${ }^{2}$ Law and Political Science Department, North China Electric Power University, China \\ alanhudie1230123@163.com, byuanxinsun123@126.com
}

Keywords: Social management innovation, Common people, Legal consciousness, Country's behavior.

\begin{abstract}
Based on sociology professor Xueyi Lu of the theory which citizens is divided into ten classes, based on the questionnaire investigation, visiting survey from all walks of life, the present situation of different class people's legal consciousness, basic on living habits and tendencies of law propaganda way has a certain degree of understanding. Based on the purpose of survey on different reaction of law, we put forward different ways to improve the legal consciousness of people.
\end{abstract}

\section{Introduction}

Since 2011, "happiness index" has become a media and government all over the world focus words; it is undoubtedly the progress of The Times. We can be "happiness index" into various subdivision indexes, but it is the cornerstone of only one: the sense of security. The so-called sense of security is the possible danger or risk of physical or mental feeling, as well as individual in dealing with the strong/weak feeling when doing things, mainly for certainty and control. Of the citizen's happiness is not and directly contacted with the people of wealth, wealth brings happiness is extremely limited. Both the rich and the poor, security is one of the source of the sound of the rule of law. Get sense of security from the aspects of legal system and the judicial practice and should be legal security, and went up to face legal security and legal issues in dealing with life on the degree of trust and apply the law two aspects. Law should be done fundamentally groups to the size of the trouble back at home. The problems now society, such as the application in all aspects of life "through the back door, into the administrative organ to find a relationship and the hospital want to let the person know is introduced, and the relatives of the village chief conflict most people choose to be passive and the reasons for the phenomenon at the end of the day or the lack of" security ", mistrust of the administrative organs, mistrust of the health care system and mistrust of the managers, and so on. This should be the pillar of people's psychological support is constantly shake, shake the power not only comes from those who believed in a privileged group, fundamentally, this should be a solid "foundation" in the act of makers and executors of trimmed by the impact of pieces. In view of the fundamental problem people lack of legal consciousness, we should suit the remedy to the case.

\section{The law of security is very important for social development}

\section{The ascension of legal security helps to social harmony and stability.}

Law is the rule of the society, only when more people follow the rules can it plays its role. Law works for the majority of people, but when it only used by a small fraction of managers and senior members of society, its role can't be truly implemented. Public security law ascension along with the ability of the two aspects, namely the understanding of law and legal application, only the two aspects of the ability to get the real leap ascension can truly realize the rule of law society in China, the realization of rule by law in China dream, finally realizes the social harmonious and stable development, the ultimate goal of the lives of the people peace and happiness. 


\section{The ascension of legal security helps to improve the well-being of the people.}

What people expect more is the stability of the ordinary, not the instability rich. Compared with economic development, the harmony and stability of life, heart full of a sense of security is the real needs of society in general. China's rapid economic development, huge wealth more concentrated in the hands of a few people, made the masses of the people in life is to experience the "sweet" the rapid development of Chinese society. But in the ensuing social problems let everybody's happiness compared with the former may not differ, concentrated wealth of a few people who will be the cause of China's GDP growth to other countries may be closely linked to security. Chinese law to protect their wealth is not intact; it is also the embodiment of the lack of a sense of security.

\section{The ascension of legal security helps the economic take-off.}

Under the background of rapid economic development, the law's not timely update cannot adapt to the requirements of economic development. If the system of spiritual civilization and rules can't adapt to the development of material basis, it will result in material development bottleneck and retreat. Law to provide guarantee for economic development, the development of economic subject legal security benefits its bravely on the economic front, not because of the lack of legal security cringe, ponder and the policy of the country.

\section{The results of the investigation}

To enhance national security law, the national government need do something in two aspects; first improve the national's understanding and the trust in law, and then the ability to use it.

\section{The main data of the investigation}

Questionnaire respectively according to different classes have different topics, with public subject and special two kinds, we evaluate the citizen's legal consciousness through public topics. We evaluate the citizen's legal security through special topics. Through the results of the investigation, we got that Is a big gap between the citizens' legal consciousness and legal security. There are $3.71 \%$ of the state functionary has low legal security but compared with agricultural, there are $77.79 \%$ of them has low legal knowledge and low legal security. Most of them Mistrust of the law.

Now when some farmers rights and interests are violated, produced by thoughts of litigation means to safeguard their rights, but due to the traditional ethics is deeply rooted in their hearts, after a painful struggle, many people still can't get out of the ethics of vortex, didn't take the way of action to protect our rights. Although contemporary farmers received the baptism of modern civilization, but still at the bottom of the residue of ancient impulse.

\section{Problems at all levels}

In the aspect of national's understanding and trust in laws, in our "legal consciousness of ordinary people and the countermeasures" research process, 1) The national and social management have a higher dependence of law, but most people think that, although the law is still not perfect, but with the development of society, the law will be gradually improved and adapt to the economic system. It also reflects the legal development of confidence is higher; 2) In private entrepreneurs professional and technical personnel, managers of the legal trust investigation, they have high professional legal trust and degree of application of law, can make full use of their knowledge and the channel of his own problems by legal ways to solve the problem 3) In the investigation of normal individual industrial and commercial households and business services personnel, opinions on the legal status of most people are at the free degree. They are not clear about that the status of legal development and its development is not adapted to the local. It also appeared in the process of legal application, believe in law, but do not understand the protection of rights and interests through what way, what kind of rights can get protection from the law. Besides some criminal cases and some typical cases, little do they know; 4) For agricultural worker social stratum, industrial workers and urban unemployment and half unemployed people, the world of law is a sacred world, is a 
world that exclude, even abandoned them. In the interview process, most of the respondents exhibited two almost extreme reactions, one is very advocating law, which thinks the law is necessary in this society, and it will be disordered if there is no law in the world. Another reaction is that, the law is only a tool for those powerful and wealthy people to serve themselves; they completely make themselves beyond the law, even think of themselves as legal outcast. Although the two extremes, but their large common point is that, he is not in a legal world, their lives very far from law.

This indeed is the rule of man and rule of law. In China there never build the real rule of law. In the county, people usually say, of course, the effectiveness of the law is larger than the effectiveness of the county magistrate, but true is by the county, the county magistrate said may be bigger than the constitution.

\section{The way to solve the problems}

To solve the "disease", only apply medicine according to the indications worked. As for states, private business owners, managers, professional and technical personnel, their legal sense of security is relatively high. For the individual industrial and commercial households, industrial workers and business people, their life experiences provide some knowledge of the law for its legal security, certain sense, but its legal application ability is poor. In this class, we should be on the basic rights and obligations of the popularization education base, to make them understand what can the law in life as its right to protect their basis. For the agricultural laborer, the main problem is the ignorance of the law, do not understand, so it is easy to has its own speculation in some problems, draw the wrong consciousness. Therefore, in this class, we should conduct propaganda from the most basic knowledge of law, some close to the livelihood of the people of the popularization of legal knowledge, the people love to see and hear forms of propaganda, from the perspective of agricultural workers living habits, improve the legal sense of security.

\section{The way to improve people's legal security}

In the binary opposition of legal discourse, elite are commonly used to refer to the dominant position legal scholars under the modern legal system, legal thinkers and legal professionals, etc. The mainstream concept of legal scholars and thinkers tend to through the legislative way to obtain the official expression, and social common recognition and acceptance.: people level of legal consciousness, legal consciousness of lawmaking lag and mass level of legal consciousness of law applicable legal consciousness lag.

According to the surveys, the law consciousness and sense of security is a big difference between people. In order to solve the legal sense of security's "short board", we should emphasize the strength in the legal sense of security for the lowest number of people, total number of large agricultural worker social stratum.

\section{For agricultural workers}

For agricultural workers, we may start with some confusion, but when know their life experience, we understand, this is as excusable. First of all, in the aspect of life management, in this class, agricultural laborers are occupying the vast majority of the overall. Their living places, the countryside, are the implementation of the autonomy of villagers. The villagers themselves that elect, belonging to the "rule of man", the work in the basis is self-breaking or voting judgment. The legal basis is few, and the election of village legal literacy needs to be fastidious, and, in practice, there are a lot of villages management and the two sets of phenomena, like managers publicity to their village like back mumbo-jumbo are introduced, but the villagers are indeed confused. We may not reach the real rural propaganda, only with the investigation, the true feelings of speculation over. And in the modern rural, in order to have a better life, agricultural laborers go out to work, but because of the lack of legal aspects, when they encounter the arrears of wages and other grievances, they do not know how to use legal means to resolve disputes. In order to solve these problems. 
1) First of all, truly strengthen the cultivation of the legal consciousness of village; suggest that in the village after the election, given a training about law and national policy in a real office before the period of three to six months, aiming to lay a foundation to solve the farmer's problem in the future. Let the legal application to agricultural laborers to life; let the agricultural laborers to be keenly aware of the legal benefits, so as to enhance their legal sense of security.

2) Provide legal aid and legal support for rural. Even if the legal consciousness has increased, it still cannot really understand the intention of legislation, then we need professional guidance's to the legal analysis and application. It can be funded by the state to provide funding for the provision of legal aid in rural institutions, this mechanism may be a mechanism of law firm, the people's court, and the people's procurator ate. The villagers can really solve the life problem institutions, national support after a period of time, the agricultural labor who knows certain legal knowledge, can let the supporting mechanism independent operation.

3) Legal talents in universities is the legal industry reserve army, really clear to build colleges and rural is connected to agricultural workers, college personnel and the national three side. The college students of designated rural social investigation and rural agricultural workers living habits of study, can quickly improve the legal consciousness of agricultural laborers, but also can improve college students' sense of social responsibility and mission, to improve the understanding and application of professional knowledge, when the society, will also look into all aspects of social surface, reach for social harmonious efforts target.4)Social needs to promote the rule of law is the intrinsic motivation, and development such as economic conditions improve, the quality of life needs to be farmers in less developed areas of the current widespread and pressing needs. Therefore, the improvement of farmers' legal consciousness not only focus on the content of the legal knowledge, ideas and consciousness, improve the farmer's economy into the way, economic level, the quality of life is the inherent requirement of legal consciousness.

\section{Conclusion}

As one of a main index, the ascension of legal security of legal security should get legal support and efforts, and it should be a real leap forward development of law through the basic state system reform and the upper design, then can adapt to the economic development, achieve economic take-off.

\section{Acknowledgment}

This research is supported by Investigation of ordinary citizens' legal consciousness present situation. (20132078).

\section{References}

[1] Jianxue Yang. Framework of Rule of Law in the Judicial Innovation of social management [J]. The applicable law. 2013(4):48.

[2] Journal of Anhui Agricultural Sciences2012,40(9).

[3] Government Legality 2012 (36).

[4]THE JOURNAL OF YUNNAN ADMINISTRATION COLLEGE2007,9(1).

[5] Chunfeng Wang. Concerning the Lack of Legal Faith from the Legal Instrumentalism [J]. Legal System and Society. 2010. (10):6.

[6] People's Tribune 2013 (32). 